\title{
Economics
}

2021; 10(2): 64-67

http://www.sciencepublishinggroup.com/j/eco

doi: $10.11648 /$ j.eco.20211002.14

ISSN: 2376-659X (Print); ISSN: 2376-6603 (Online)

\section{Economic Devlopment and Growth with Historical, Past and Present Perspective}

\author{
Iqbal Shaukat \\ Financial Management Association, University of California, California, USA
}

Email address:

professionalstudent2020@gmail.com

\section{To cite this article:}

Iqbal Shaukat. Economic Devlopment and Growth with Historical, Past and Present Perspective. Economics. Vol. 10, No. 2, 2021 , pp. 64-67. doi: $10.11648 /$ j.eco.20211002.14

Received: April 21, 2021; Accepted: June 23, 2021; Published: June 29, 2021

\begin{abstract}
I discussed in this paper about the role of economic development. Economic development is only way that we can achieve the goal of progress. I discussed in this paper how the nations started the way of devlopment. This is my effort that I teach the people through this people that economic devlopment is very important for every nation. After the destruction of war, nations feel that economic progress is only possible with good policies. After the adoption of good policies the many nation achieved the goal of devlopment. For example who faced the destruction in second world war. Japan started the strategy of economic devlopment. Japaness strated upon the need of high efficiency rate in every sector. I study the various books and references regarding economic development. I compare the data of economic devlopment of various devloped and under devloped nation. The main object of this paper to provide the precis information to student, Business consultant, future economist, and the person who have no education of economics. The conclusion is that with out economic development the nation cannot achieve any goal. Economic development is provide the guide line how the destination and goal of goal can be achieved.
\end{abstract}

Keywords: Economic, Devlopment, Resources, Nation

\section{Introduction}

Economic development is the very important for every nation. discussed in this paper the historical perspective of economic development discussed in this paper about the structure of market economy. In this paper I highlighted about the economic development and growth of developed countries highlighted how the some developed countries adopted the goal of Economic development after the second world war. discussed in this paper I create link between the professional education and economic development. My main objective to educate the people regarding the Economic development with historical and global perspective.

\section{Historical Perspective of Economic Development}

Economic development is the goal and objective of every man because it is only way humanity can enjoy the life. In the early age man started the trade for the earning. Economic development is a natural process which attract the man to stream line all the function of commerce. When the trade was started between the cities the humanity was very ambitious about the development. Man fulfilled their need through trade which is called the barter system after that the enhance of economic system man started the metallic money. When we study the Chinese civilization and sanseis we can found all these evidence from the history of civilization the barter system and metallic money was used. After the enhancement of population of various part of world they started the trade on economic lines. In very early centuries the various tribe move to such areas which suitable for economic activities. For examples many tribe in Europe move to Baltic Sea and the some area which are suitable for trade. We can say this was base of economic system. With expansion of Roman Empire. Roman Empire made the conducts of trade. When colomas discovered the American in 1492. Columbus want to reach the Asia started the new route between Asia and Europe. Some trade delegation visited the area which is called the USA for trade routes. When the colonization of USA was started by Spanish, French, English, Russian they 
established various way of trade between the continents Atlantic and Indian Ocean.

During the colonization many colonial power produce the infrastructure in the countries because they want to organized himself. During the era of colonization various trading companies was established by the Great Britain, France, and Portages. During the eighteen and nineteen invention inventions was discovered was made. Such as Microscope and aero plane and radio and Telephones. They brought the new line of business and economic development. During the eighteen century many minerals was discovered such as petroleum, Cooper, Gold and Silver [1-3].

\section{Divelopment and Desoveries of Resources}

In 1865 In Virginia first oil reserve was discovered. During eighteen century many mineral reserve discovered by nation such as great Britain and France. In early of the nineteen century first oil reserve was discovered in Persia. After all developments human life new turned.

Market Economy: Market With the passage of time marketing structure was placed. In 1792 New York stoke exchange with the agreement of thirty brokers. Wall Street was establish by Wall Street came in to being in seventeen century by the Dutch in New York. London stock exchange came in to being in 1801 in London for the business and regulate in of securities. Many Multinational came into being in $17 \& 18 \& 19$ century such as Nestle in 1865 , Lever Brother 1885, Cambridge university press in 1534, Barclays in 1690, Citi in 1812, British petroleum Ltd 1910, Cadburys in 1824 timing 1706 [3-8].

\section{Education Institutes}

Education institution have the big share in economic development. In many education institution established with the intention to give the economics education on the academic level such as

Many business institutes came in being. In 1819 the first business came in to being in France. In 1857 in hungry Budabest. In USA the Hass School came Into being in 1898 in university of California and wert son school came in to being in pensalvenya USA 1898. The Harvard university established started masters program and establish research center regarding the Business management studies in 1908. In 1916 university of Chicago started the Doctorate (PHD) programe. In 1946 first business school in Indian state Jharkhand. London school of economics came into being in 1895 built by fibrin socitey. With the intention of give the economics education on the academia level. Many school of thoughts was formulated, because they define the economics First of all Adam smith defined the economics in 1897. He stated the economics as knowledge of wealth. And other school of thought such as Robbins and Alford marshal and recado and kenciyas. In nineteen century money paper was introduced with the intention to adopt the economic system. In 1917 Federal Reserve Bank of USA was established. After the indepdence of Use suitable economic system was estalised.

Economic reforms and strategy by different nations.

Abraham Lincoln introduced the law against the slavery. In 1919 the American president true man inaugurated speech of economic development he stressed upon the need of economic development regarding the development of infrastructure and human capital. After the second world many countries started the path of economic development with the intention of welfare and harmony. Japan started the way of development. They implemented tool of quality control of product. They introduced the system of just in. They managed everything on the micro level. They achieved the target of economic development staidly in the sixty about $10 \%$ in eighty and $4 \%$ in sixty. Japanese made the disaster planning against the calamities especially in 2011 Japanese controlled the population growth. In Singapore got the indepdence from Malasyia. Singapore are not the agriculture economy they achieve the target the economic development with the implementation of rules and regulation in economic sector and other part of human life. Argentine is the country who faced the economic disaster before the few years. They introduced the policy abolished of stat control on the various sectors. Argentine established the good relationship with neighboring with USA and Canada and Brazil Argentine promoted the agro base industry. In argentine value additional tax was introduced with the intention of highest revenue and equality among the various sector. China is the biggest example of economic development. They achieved the highest growth of economic development in 2010 about $12 \%$. Before some decades they face economic disaster with the economic growth of 2.5 in 1960 Chinese got achieve the target of growth steadily i every sector. Chinese completed the many project such as three George dam situated yawing district in the province of Hubaiwith the capacity to produce the energy $22400 \mathrm{Mv}$. Chinese introduced the concept of public private patnership in the the business. Chinese president xenzemin abolished the policy of state control. Xenzemin introduced the reform regarding deregulation. In 1948 when china got independence under the dynamic leadership of Mao. Chinese introduced the justice system on the micro level which helped the nation to resolve the problem at the door step. The implantation of rules and regulation in china is very satisfactory as compare to the other developed countries around the world. Brazil is the role model for developing economy. Brazil government direct give financial support to poor people. Brazil government supported the agriculture and agro base industry with various policies. Brazil is only country who achieved the high ratio of tax to GDP. Mexico is the example of development by the help of international relation. Mexico has forty trade agreement around the world. Mexico has duty free region for some countries including USA [5-9]. 


\section{Some Countries Are Symbol of Economic Devlopment}

All the nation should fellow the path way of devlopment. Many countries are the examples for other world. Deregulation, cottage industry, Micro finance, Motivation economic and management policies. Such economy got the destination of Economic development with steadily and smoothly. For example in china and India and Japan have the economic growth target of two percentage, through this way they achieved the economic growth and Devlopment. Economic growth is not roses way, it can be achieved through sacrifices and control on monetary expension. Economic development is the dream of entire nation. All the nations of the world have desire of economic development. Economic devlopment is only way which give the nation how to spend the prosperous life. Economic devlopment is very ken for every nation. Some devloped nation was backward before some decade's, but due to some good economic strategy [8-12].

\section{Two Periods of Economic Development after the Post World War}

Japan faced economic disaster after the second world, because of economic growth strategy they started the journey of devlopment, Japan provide the professional and technically education to entire population. They adopted the good management techniques which help the Japan the started the economic growth. In the few years they avhieved the highest growth of economic devlopment. Japan economic model was one examlainery model for entire region. Japan have the main share in Automobile and in the electric industry. China is one of great example of Economic growth and Devlopment. They organized their economy very wall. They organized all the sectors of economy Agriculture, industry, Small medium exchange industry.

chieve of Economic growth and Devlopment

China started the capital projets like dams and industrial estates. China government announced the policy of deregulation, the policy of deregulation was very attractive for the foreign investment. Chines governments announced many incentive for foreign investors, as a result of this polices of deregulation the Chinese economy achieved the highest growth of economic development In the recent Chinese government adopted such foreign polices specially relationship with other countries they achieved the confidence of foreign investors. Banagladesh was the least devloped countries of the world, before the some years they design the Economic polices which was very beneficial for the entire population. Bangladesh achieved the highest growth in tactile sector and became the main exporter of tactile product. In Bangladesh they introduced and implemented the micro finance sachems for cottage base industry. In most recent years they achieved highest rate of economic growth. Vietnam faced the economic disaster before some decade's, Vietnam organized the human resource and organized the cottage industries, which creat the many employment opportunities. The fector of economic devlopment is that increase in industrialization [11-16].

\section{Professional Education Link with Economic Development}

Professional education, these are the main tools which can play the vital role in the devlopment of countries. Some countries are the lesson for the entire world if they work heard with spirits the goal of economic devlopment can be achieved, if countries hire good economic expert they can achieve the goal of economic growth and devlopment. In some countries the political stibility is not certain, but inspite of all they achieved the goal of economic development. In various countries where the political stibility are very fine. They achieved the goal of Economic devlopment. Some countries got achieved of high target of growth in Agriculture Reforms regarding Economic devlopment.

Nepal, combodia, India. Such countries introduced the special reforms in relevant sectors. Economic devlopment possible when all the countries adopt such polices which is according to the spirite of economic and Economic devlopment. We should consider all the sectors regarding economic devlopment. This is not justified that government provide the incentive to one particular sector. Government should provide the equeal opportunity to every sectors. Economic devlopment is the base of every society [4-7].

\section{Agriculture Sector Role in the Economic Growth}

Agriculture Directly link with economic growth of the country. When we measure the Gross domestic product we measure the goods and services. When we estimate the Agriculture goods the Agriculture goods are included in the Gross domestic product. Agriculture sector are very vital for country economy. Country economy can be boost through the Agriculture goods. Agriculture goods provide the better infrastructure of employment to the nation. Agriculture sector provide the better employment opportunities to the majority of population. In various devloping countries and least devloped countries the literacy rate is very low as compared to devloped nation. In various third world countries the education system is not satisfactory, in this regard the Agriculture sector play the vital role of economy. Economic devlopment is the dream of every nation. Agriculture sector is the mother of economy. In various countries like Vietnam, combodia, Burma, Nepal they are very backward in many areas of economy, such countries agriculture sector play the vital role in economy. In many African countries the Economic growth is very low. People of such countries depend upon the Agriculture sector. World financial agencies can play 
the vital role regarding the devlopment of Agriculture sector. One world Agriculture devlopment Bank should be established regarding the financial grant of countries, which are total depend on the Agriculture sector. Agriculture sector play the dynamic role in the industrial devlopment. Agriculture sector is the main source of raw material to industrial sector. If the industrial sector and Agriculture sector work to heather for the devlopment, and have the good working relationship the goal of the devlopment can be achieved. Some time lot of unrest between the industrial and Agriculture sector it creat the disperity between the Agriculture sector and industrial sector. Government and industrial community should pay the good support price to farmer and incentive to Agriculture sector, the Agriculture sector will boost and also increase the producetvity of industrial sector. We can achieve the industrial growth if we maintain the balance economy in the country. Government should announce the good Agriculture support price policy. Which can be enhance the country economy. When we study the concept of Economic devlopment we shall get the concept of equilibrium role of all the sector. Government should included the subject of Agriculture economics in the syllabus of economics, this step will creat the awareness of Agriculture sector. The role of Agriculture sector is very important in the country Economic growth. Economic growth help to increase in national income, percapita. Balnce of payment can be improved through the Agriculture sector. Thus we can say that role of Agriculture sector in the world economy is very important [1-4, 12-16].

\section{Conclusion}

Economic development is the goal of every nation. Good way of economic development provide the opportunity to entire nation. When the national income rise the per capita income increase. Good economic system provide the health system and infrastructure system to entire nation. For example one family earned the income. As a result of this income the saving and consumption will increase. This increase in the saving and consumption will rise the investment in the country. When all the segments of society spend the prosperous life that country will ultimate achieve of economic development. If we consider this scenario when one country not developed due to the same reasons, the consumption and investment rate is very low as a result of adverse situation. The country will face economic disaster in the form of poverty and unemployment and inflation rate. All the regime should establish such economic order which provide the employment function and other facilities. Developing nations and poor nation regime should get lesson from the developed countries. Developing countries and poor countries should make and formulate and adopt such economic principles which adopted by the some developed nations. Thus we can say that is why of development is only way which provide the happy and prosperous life to entire nation.

\section{References}

[1] Finnemore, Martha (1996). National Interests in International Society. Cornell University Press. pp. 89-97. doi: 10.7591/j.ctt1rv61rh.

[2] Jaffee, David (1998). Levels of Socio-economic Development Theory. Westport and London: Praeger. p. 3. ISBN 9780275956585 .

[3] Seidman, Karl F. (2005). Economic Development Finance. Thousand Oaks: Sage Publications. p. 5. ISBN 9780765628176 .

[4] Greenwood, Daphne T.; Holt, Richard P. F. (2010). Local Economic Development in the 21st Century. Armonk and London: M. E. Sharpe. pp. 3-4. ISBN 9780765628176.

[5] R. Conteras, "How the Concept of Development Got Started" University of Iowa Center for International Finance and Development E-Book (1) Archived 2008-10-08 at the Wayback Machine.

[6] Escobar, Arturo (November 1988). "Power and Visibility: Development and the Invention and Management of the Third World". Cultural Anthropology. 3 (4): 428-443. doi: 10.1525/can.1988.3.4.02a00060. ISSN 0886-7356. S2CID 55332626 .

[7] "Archived copy". Archived from the original on 2006-10-14. Retrieved 2009-10-14.

[8] Mansell, R \& and Wehn, U. 1998. Knowledge Societies: Information Technology for Sustainable Development. New York: Oxford University Press.

[9] Schumpeter, Joseph \& Backhaus, Ursula, 2003. The Theory of Economic Development. In Joseph Alois Schumpeter. pp. 61116. doi: 10.1007/0-306-48082-4_3.

[10] Gerschenkron, Alexander (1962). Economic Backwardness in Historical Perspective. Cambridge, MA: Harvard University Press.

[11] See Michael Todaro and Stephen C. Smith, "Economic Development" (11th ed.). Archived from the original on 201806-23. Retrieved 2012-03-30., Pearson Education and Addison-Wesley (2011).

[12] Sen, A (1983). "Development: Which Way Now?". Economic Journal. 93 (372): 745-62. doi: 10.2307/2232744.JSTOR2232744.

[13] Hirschman, A. O. (1981). The Rise and Decline of Development Economics. Essays in Trespassing: Economics to Politics to Beyond. pp. 1-24.

[14] Simon Kuznets (1966). Modern Economic Growth: Rate, Structure and Spread, Yale University Press, New Haven, Connecticut.

[15] Kenneth Shepsle and Mark Bonchek (2010), Analyzing Politics, Second Edition, Norton, pp. 67-86.

[16] G. Bingham Powell (2000). Elections as Instruments of Democracy: Majoritarian and Proportional Views. Yale University Press, New Haven, Connecticut. 